Título da página eletrónica: International Association for the Study of Religion and Gender

URL: http://associationreligionandgender.org/

\title{
Alberta Giorgi
}

\section{OpenEdition}

\section{Journals}

Electronic version

URL: http://journals.openedition.org/rccs/6428

DOI: $10.4000 /$ rccs. 6428

ISSN: 2182-7435

\section{Publisher}

Centro de Estudos Sociais da Universidade de Coimbra

Printed version

Date of publication: 1 September 2016

Number of pages: 149

ISSN: 0254-1106

\section{Electronic reference}

Alberta Giorgi, «Título da página eletrónica: International Association for the Study of Religion and Gender », Revista Crítica de Ciências Sociais [Online], 110 | 2016, Online since 26 September 2016, connection on 25 September 2020. URL : http://journals.openedition.org/rccs/6428 ; DOI : https://doi.org/ $10.4000 /$ rccs. 6428 


\section{Espaço Virtual}

\section{Título da página eletrónica: International Association for the Study of Religion and Gender URL: https://associationreligionandgender.org/}

The International Association for the study of Religion and Gender is the outcome of a three years networking programme called 'Interdisciplinary Innovations in the Study of Religion and Gender: Postcolonial, Post-secular and Queer Perspectives'. The programme brought together some of the leading scholars in the field with the objective of developing research project proposals and grant applications and establishing a structural research network for the study of religion and gender. IARG, which includes the most relevant research centres and scholars active in the field of religion and gender, was launched in February 2015. The association organizes a biannual conference, and the website operates as a platform for networking and collecting information on call for papers, projects, and people in the field. The blog section provides updated and regular information on the most recent books and articles, and call for paper for collective edited publications. Moreover, the IARG publishes the open access peer-reviewed journal Religion and Gender, accessible from the same website. It is the first refereed online international journal dedicated to the systematic study of gender and religion in an interdisciplinary perspective, and it is published twice a year.

In addition to the information on conferences and project, and on people working in the field, the website will also include interactive/virtual educational modules for students and scholars. In this sense, it aims to provide useful resources for learning and teaching, in a recent and thriving interdisciplinary field. Being extremely recent, the website has still to develop all its potentiality. However, it is the most updated and complete website for interdisciplinary studies on gender and religion.

Alberta Giorgi

\section{Título da página eletrónica: The Immanent Frame. Secularism, Religion, and the Public Sphere URL: http://blogs.ssrc.org/tif/}

The Immanent Frame is an online forum that publishes interdisciplinary perspectives on religion, secularism, and the public sphere. It has been founded in October 2007 in conjunction with the Social Science Research Council's program on Religion and the Public Sphere, with the aim of establishing a virtual platform collecting contributions (mainly by invitation) from a number of leading scholars. Today, the website covers a wide range of topics. The section "Essays \& exchanges" features original contributions organized by topics: Religion and the public sphere, Religion and world affairs, Religion in American politics, Rethinking secularism, 
and The science of religion. Each topic, in turn, includes a number of subtopics. Religion and the public sphere, for example, include an interesting discussion on Religion and digital culture. The "Essays \& exchanges" section is conceived as an ongoing conversation, complemented by the readers' comments. In the "off the cuff" section, the editors pose a question to a handful of leading thinkers and scholars, and invite a quick and succinct response. Questions range from summer readings to multiculturalism in Europe, elections and religion, etc. What is not covered by the other sections ("Essays \& exchanges", and "off the cuff") is included in the "here and there" section, featuring unstimulated or unguided reflections on current affairs and news, as well as broader reflections. The other two sections, "publications", and "the book blog", provide information on recent books and current researches. More specifically (and extremely inspiring), the book blog section encourages comments, reflections, and discussions around recently published books in the field of religion, secularism, and the public sphere. Particularly interesting is, for example, the wide discussion around Charles Taylor's A Secular Age, animated by many leading scholars.

The website is particularly interesting as a specific form of academic debate, rigorous and thorough, but at the same time freer and faster than journal articles, and more focused. It is extremely inspiring not only for scholars in the field but, more broadly, for all the people interested in the role of religion in current societies, and in connection to both long-term processes and specific events. The relevance of blog posting for academics has been repeatedly pointed out, in recent years, as well as the difficulties connected to such a practice. The Immanent Frame represents thus a successful experiment in this direction, able to make academic topics accessible to a wider audience while, at the same time, maintaining a high level of discussion.

Alberta Giorgi

\section{Título da página eletrónica: Center for LGBTQ and Gender Studies in Religion (CLGS) URL: http://clgs.org}

The Center for LGBTQ and Gender Studies in Religion was established at the Pacific School of Religion in Berkeley, California, in 2000, and aims at supporting scholars, faith communities, and LGBTQ people and organizations through gathering and providing study materials on the history of LGBT religious movements.

CLGS website offers, among other things, online resources, such as the CLGS Archives Project - which provides materials on the history of religion and LGBT issues in the USA - and a wide variety of support material for associations and individuals interested in the matter.

CLGS is also affiliated with the LGBT-RAN - Lesbian, Gay, Bisexual, and Transgender Religious Archives Network (www.lgbtran. org), an online archive for the study of LGBT religious movements around the world.

Tatiana Motterle 
Alberta Giorgi

Centro de Estudos Sociais, Universidade de Coimbra

Colégio de S. Jerónimo, Apartado 3087, 3000-995 Coimbra, Portugal

Contact: albertagiorgi@ces.uc.pt

\section{Tatiana Motterle}

Centro de Estudos Sociais, Universidade de Coimbra

Colégio de S. Jerónimo, Apartado 3087, 3000-995 Coimbra, Portugal

Contact: tatianamotterle@ces.uc.pt 
